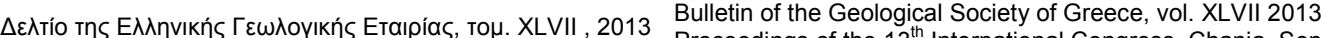
Proceedings of the $13^{\text {th }}$ International Congress, Chania, Sept.

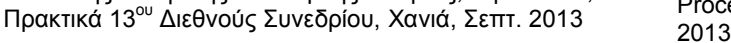

\title{
METAMORPHIC RECORD IN METALHERZOLITE POCKETS WITHIN THE VIRSINI METAHARZBURGITE FROM THE KECHROS HP METAMORPHIC COMPLEX IN EASTERN RHODOPE, GREECE
}

\author{
Mposkos E. ${ }^{1}$ and Perraki M. ${ }^{1}$ \\ ${ }^{I}$ National Technical University of Athens, School of Mining and Metallurgical Engineering, 9 \\ Heroon Politechniou St., 15773, Athens, mposkos@metal.ntua.gr,maria@metal.ntua.gr
}

\begin{abstract}
The Virsini antigorite serpentinite from the Kechros HP metamorphic complex in eastern Rhodope is a serpentinized harzburgite with pockets of lherzolitic composition. In the metalherzolites the mantle assemblage is $\mathrm{Ol}-1+\mathrm{Opx}+\mathrm{Cpx}-\mathrm{C}+\mathrm{Cr}-\mathrm{Spl}$. The metamorphic assemblage is Atg $+\mathrm{Ol}-2+\mathrm{Cpx}-2+\mathrm{Ol}-3+\mathrm{Chl}+\mathrm{Tr}+\mathrm{Cr}-\mathrm{Mag}$. Antigorite and Cr-magnetite formed in an early stage of the metamorphic event. With increase in metamorphic grade olivine (Ol-2) was formed at the expense of antigorite and with further increase tremolite, olivine (Ol-3) and chlorite were formed at the expense of clinopyroxene and antigorite. P-T conditions of $\approx 1.7 \mathrm{GPa} \approx 570^{\circ} \mathrm{C}$ are recorded in neighbouring eclogites. For the temperature of $570{ }^{\circ} \mathrm{C}$ the reaction $\mathrm{Di}+\mathrm{Atg} \rightarrow \mathrm{Ol}+\mathrm{Tr}+\mathrm{H}_{2} \mathrm{O}$ occurs at pressure of $\sim 1.2 \mathrm{GPa}$ suggesting that the stability field of the mineral assemblage Atg $+\mathrm{Ol}+\mathrm{Tr}$ in the metalherzolite is crossed during decompression.
\end{abstract}

Key words: Antigorite serpentinite, high pressure, Kechros complex, Rhodope.

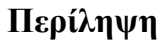

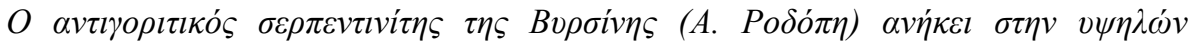

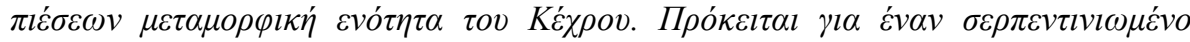

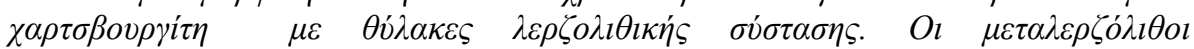

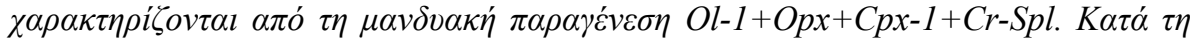

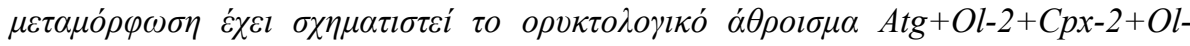

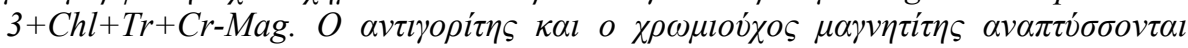

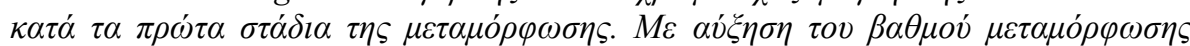

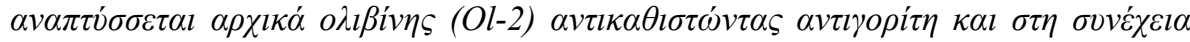

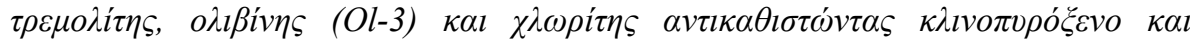

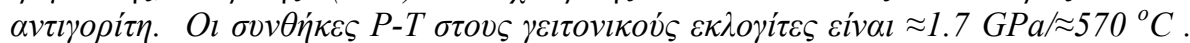

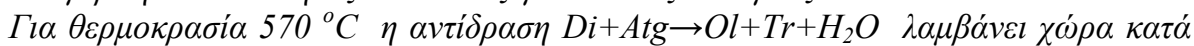

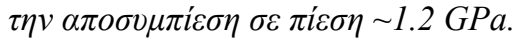

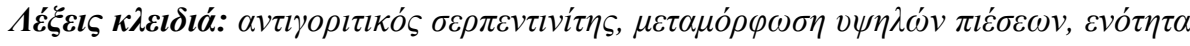
K'́x $\chi \rho o v$. 


\section{Introduction}

Peridotite bodies occur in numerous high-pressure (HP) metamorphic terrains within orogens involving major continental collisions. They usually form lens-shaped masses, normally within metamorphosed continental crustal rocks, but also within rocks of oceanic affinity. The lenses range in size from small (ca. $1 \mathrm{~m}$ across) to enormous ( $>100 \mathrm{Km}^{2}$ in outcrop area). In general, peridotites in gneiss terrains record the emplacement of mantle material into the continental crust and reveal the composition of the upper mantle and the nature of mantle/crust interaction processes (Brueckner and Medaris, 2000). Peridotites in metamorphic terrains potentially provide excellent information about temperature regimes. Phase relations for peridotites of harzburgitic and lherzolitic bulk compositions have been used to decipher details of the metamorphic evolution of a terrain (i.e.Trommsdorff and Evans, 1974; Mposkos et al., 2010; Padron-Navarta et al., 2011).

The Rhodope Domain extends over large areas of northern Greece and southern Bulgaria. It incorporates several tectonic slivers of reprocessed pre-Alpine crust, including Variscan granitoids, post-Variscan oceanic and continental margin sediments as well as igneous rocks subsequently subjected to HP metamorphism(s) (for protolith- and metamorphic ages see references in Burg, 2011; and Liati et al., 2011).

Mposkos and Krohe (2000) and Krohe and Mposkos (2002) subdivided the Greek part of the Rhodope domain into several tectonometamorphic units. These segments differ in P-T conditions during their Alpine HP metamorphism, and timing of exhumation. In the eastern Greek Rhodope the upper tectonic unit (Kimi complex; Mposkos and Krohe, 2000; 2006, Figure 1), shows a late Jurassic high-temperature eclogite facies, followed by Cretaceous granulite and upper amphibolite facies metamorphisms. The lower tectonic unit (Kechros complex; Mposkos and Krohe, 2000) experienced a low temperature eclogite facies followed by albite-epidote amphibolite- to lower amphibolite facies metamorphism (Mposkos, 1989; Mposkos et al., 2012). Ultramafic rocks occur in both tectonic units.

In the Kimi complex a garnet-spinel bearing lherzolitic meta-peridotite which contains layers of spinel-garnet clinopyroxenites, indicates an early high temperature and (U)HP metamorphism followed by cooling at substantial depth associated with relatively little decompression (Mposkos and Krohe, 2006). P-T conditions of $>3 \mathrm{GPa}$ and $1235^{\circ} \mathrm{C}$ were estimated from the assemblage OlOpx-Cpx-Spl-Grt (abbreviations after Whitney and Evans, 2010). In the clinopyroxenites, garnetand spinel exsolution lamellae in clinopyroxenes, indicate that cooling started already in the garnet pyroxenite stability field. Hydration reactions like $\mathrm{Grt}+\mathrm{Opx}+\mathrm{W} \rightarrow \mathrm{Ol}+\mathrm{Hbl}$ and $\mathrm{Opx}+\mathrm{Cpx}+\mathrm{Spl}+\mathrm{W} \rightarrow \mathrm{Hbl}+\mathrm{Ol}$ indicate decompression and cooling to below 1.2-1.3 GPa at 650-750 ${ }^{\circ} \mathrm{C}$ (Mposkos and Krohe, 2006).

In the Kechros complex large bodies of antigorite serpentinites like those from Dadia and Virsini areas (Figure1) represent the mantle assemblage. However, mineral assemblages, textures and mineral chemistry data which record the metamorphic evolution of these ultramafic rocks have yet to be reported.

In this paper we provide textural relationships and mineral compositions of the primary and the metamorphic mineral phases from metalherzolite pockets occurring within the Virsini antigorite serpentinite (metaharzburgite) and compare the metamorphic P-T path of the metaperidotite with that of the surrounding crustal rocks.

\section{Geological Setting}

The Kechros Complex consists of orthogneisses, reworked migmatites (containing muscovite metapegmatite lenses), pelitic gneisses, high-alumina metapelites and scarce marbles. Large serpentinized peridotites are tectonically intercalated. Within orthogneisses, serpentinites and between serpentinites and underlying metapelites, boudins of eclogites, eclogite amphibolites and 
amphibolites occur. HP metamorphism at P-T conditions of 1.7-2.2 GPa and $570-620{ }^{0} \mathrm{C}$ were reported from the eclogites (Mposkos et al., 2012). In the orthogneisses and metapelites the HP event is indicated by the presence of high-Si phengites (Mposkos, 1989). In metapelites staurolite formed by the reactions $\mathrm{Cld}+\mathrm{Ph} \rightarrow \mathrm{St}+\mathrm{Chl}+\mathrm{Ms}+\mathrm{Qz}+\mathrm{H}_{2} \mathrm{O}$ and $\mathrm{Cld}+\mathrm{Ms}+\mathrm{Qtz} \rightarrow \mathrm{St}+\mathrm{Bt}+$ $\mathrm{H}_{2} \mathrm{O}$ suggests nearly isothermal decompression from maximum pressures of $2.2 \mathrm{GPa}$ to $0.4 \mathrm{GPa}$ (Mposkos 1989; Mposkos and Liati, 1993), implying rapid uplift. Orthogneisses and metapegmatites have Variscan protolith ages, as is indicated by Rb-Sr age of $334 \mathrm{Ma}$ of magmatic muscovite from metapegmatite; (Mposkos and Wawrzenitz, 1995) and U-Pb ages between 326$299 \mathrm{Ma}$ of magmatic zircons from orthogneisses (Peytcheva and von Quadt, 1995; Cornelius 2008; Liati et al., 2011). An U-Pb SHRIMP age of magmatic zircons from a kyanite-eclogite yielding $255 \mathrm{Ma}$ is interpreted as the age of the gabbroic protolith (Liati et al., 2011) indicating that the subsequent HP metamorphism is Alpine in age. The minimum age of HP metamorphism is limited by $\mathrm{Rb}-\mathrm{Sr}$ and $\mathrm{Ar} / \mathrm{Ar}$ white mica ages of 36-42 Ma from mylonitic orthogneisses (Wawrzenitz and Mposkos, 1997; Lips et al., 2000). Emplacement of the Kechros complex to shallow crustal levels and juxtaposition against the Kimi complex by extensional deformation between 36 and 32 Ma is constrained by $\mathrm{Rb}-\mathrm{Sr}$ biotite ages of granodiorites and subvolcanic rocks that intruded the Kechros complex and the overlying Kimi complex (Del Moro et al. 1988).

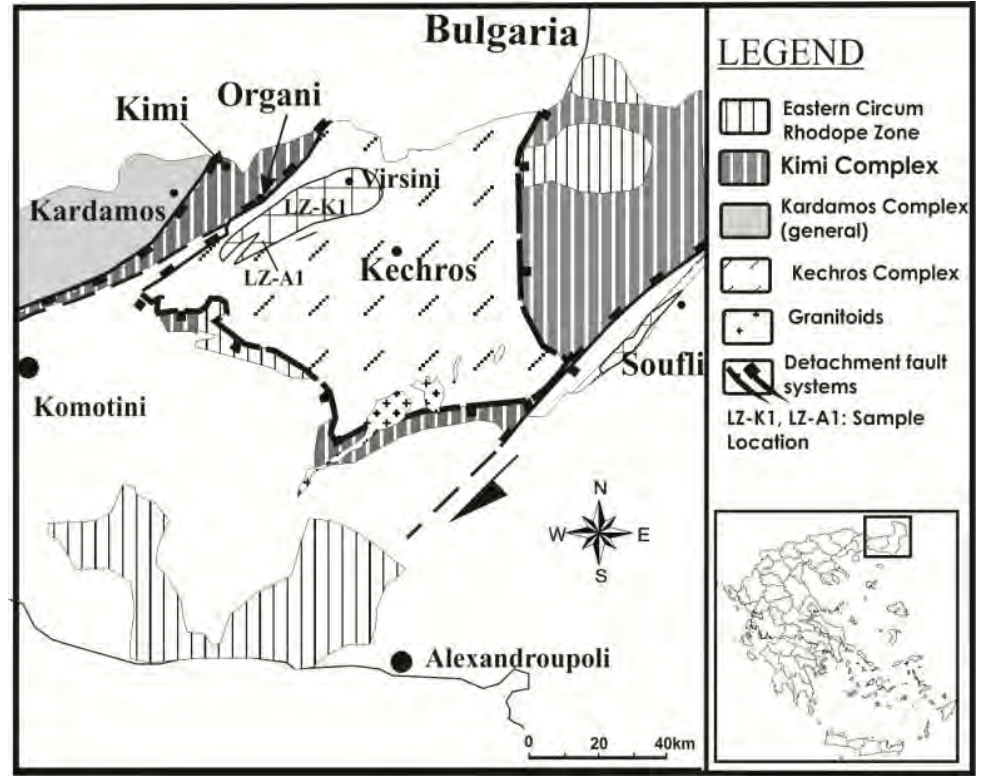

Figure 1 - Tectonic subdivision of eastern Greek Rhodope in northern Greece modified after Mposkos (1989) and Krohe and Mposkos (2002).

\section{Ultramafic Rocks from the Kechros Complex}

In the Kechros complex, metaperidotites occur as lens-shaped bodies ( 2 to $20 \mathrm{~km}$ in length and 0.5 to $5 \mathrm{~km}$ in width) intercalated between orthogneisses and metapelites. They are commonly associated with amphibolites and amphibolitized eclogites. The antigorite serpentinites from Dadia and Virsini areas (Figure 1) are the largest metaperidotite bodies in the Greek Rhodope. These ultramafic bodies contain dunitic boudins with chromitite pods, boudins of gabbroic pegmatites, diabase dykes, rodingitic gabbros and trondhjemites subsequently affected by HP metamorphism (Iliadis, 2006: Mposkos et al., 2012).

The Virsini antigorite serpentinite occupies an area of approximately $5 \times 23 \mathrm{~km}$ and has a maximum thickness of about $300 \mathrm{~m}$. It is a serpentinized and foliated clinopyroxene-bearing harzburgite with pockets of lherzolitic composition. Foliation is the result of penetrative deformation at albite- 
epidote amphibolite/amphibolite facies conditions. The foliation strikes NE-SW and is similar to that of the surrounded phengite orthogneisses and metapelites.

Table 1: Bulk rock chemical- and norm composition of two metalherzolite samples (LZ- A1 and LZ-K1) from the Virsini metaperidotite.

\begin{tabular}{|c|c|c|c|c|c|c|c|c|c|c|c|}
\hline & $\mathrm{SiO}_{2}$ & $\mathrm{TiO}_{2}$ & $\mathrm{Al}_{2} \mathrm{O}_{3}$ & $\mathrm{Cr}_{2} \mathrm{O}_{3}$ & $\mathrm{Fe}_{2} \mathrm{O}_{3}$ & $\begin{array}{l}\mathrm{Mn} \\
\mathrm{O}\end{array}$ & $\mathrm{MgO}$ & $\mathrm{NiO}$ & $\mathrm{CaO}$ & $\mathrm{Na}_{2} \mathrm{O}$ & $\mathrm{K}_{2} \mathrm{O}$ \\
\hline LZ-A1 & 40.35 & 0.01 & 1.35 & 0.42 & 8.45 & 0.13 & 39.57 & 0.31 & 1.54 & $<0.01$ & $<0.01$ \\
\hline LZ-K1 & 42.80 & 0.02 & 1.70 & 0.29 & 8.34 & 0.11 & 37.35 & 0.26 & 1.54 & 0.05 & 0.01 \\
\hline LOI & Norm & $\mathrm{Ol}$ & En & Di & CaTs & MgTs & $\mathrm{Chr}$ & & & & \\
\hline 7.0 & LZ-A1 & 72.51 & 18.96 & 5.02 & 1.58 & 1.47 & 0.67 & & & & \\
\hline 7.16 & LZ-K1 & 63.51 & 28.03 & 3.95 & 1.98 & 1.84 & 0.47 & & & & \\
\hline
\end{tabular}

\section{Petrography}

The studied metalherzolites crop out as poorly foliated to massive lenses within the antigorite serpentinite. They are composed of $\mathrm{Ol} \pm \mathrm{Opx}+\mathrm{Cpx}+\mathrm{Atg}+\mathrm{Chl}+\mathrm{Tr} \pm \mathrm{Cr}-\mathrm{Spl}+\mathrm{Mag}$. Relicts of the mantle assemblage olivine (O1-1), orthopyroxene, clinopyroxene (Cpx-1), and Cr-spinel are still preserved within an antigorite matrix. Primary olivine (Ol-1) up to $3 \mathrm{~mm}$ in size shows undulatory extinction and deformation bands. It is replaced by antigorite at the grain boundaries and along deformation bands and fractures. Aggregates consisting of isometric olivine grains (O1-2, 25-100 $\mu \mathrm{m}$ in size) overgrow $\mathrm{Ol}-1$ and are in textural equilibrium with matrix antigorite and Cr-magnetite (Figure 2a). Orthopyroxene (up to $6 \mathrm{~mm}$ in size) contains inclusions of olivine and exsolution lamellae of clinopyroxene. Orthopyroxene is preserved only in lherzolite pockets which were affected by low degree of serpentinization. In lherzolite pockets affected by high degree of serpentinization orthopyroxene is completely replaced by antigorite forming bastite pseudomorphs. Primary clinopyroxene ( $\mathrm{Cpx}-1$, up to $4 \mathrm{~mm}$ in size) is marginally replaced by thin prismatic tremolite and olivine (Ol-3). Olivine-3 forms aggregates of isometric to longitudinal grains. Scanning electron microscope (SEM) images show that the primary clinopyroxene is replaced by olivine lamellae (Ol-3), diopside ( $\mathrm{Cpx}-2)$, tremolite, antigorite, chlorite and magnetite (Figures $2 \mathrm{~b}, \mathrm{c})$. The alternating diopside, olivine, antigorite and chlorite lamellae shown in Figures $2 \mathrm{~b}, 2 \mathrm{c}$ suggest that the primary clinopyroxene contained exsolution lamellae of orthopyroxene which are completely replaced by antigorite; with increasing grade of metamorphism antigorite lamellae were partly replaced by lamellar olivine and chlorite (see metamorphic conditions). Clinopyroxene lamellae contain vermicular exsolutions of Cr-magnetite (Figure 2c). Antigorite participates with $>60 \%$ in volume in the rock. It forms up to $0.5 \mathrm{~mm}$ large and $0.05 \mathrm{~mm}$ thick flakes replacing olivine and pyroxenes. In clinopyroxene porphyroclasts, the antigorite and chlorite flakes grow parallel to the prismatic crystal faces of the clinopyroxene, probably replacing former orthopyroxene exsolutions (Figures $2 \mathrm{~b}, \mathrm{~d}$ ). Tremolite (up to $0.8 \mathrm{~mm}$, commonly $0.3-0.6 \mathrm{~mm}$ in size) is prismatic and occurs in textural equilibrium with Ol-3 and chlorite replacing clinopyroxene and antigorite (Figure 2e). Large tremolite crystals contain inclusions of diopside, antigorite and magnetite (Figure 2f). Primary $\mathrm{Cr}$-spinel is still preserved in the lherzolite pockets affected by a low degree of serpentinization. In lherzolite pockets affected by a larger degree of serpentinization Cr-spinel is completely replaced by chlorite and Cr-magnetite. This Cr-magnetite contains inclusions of diopside and antigorite. 

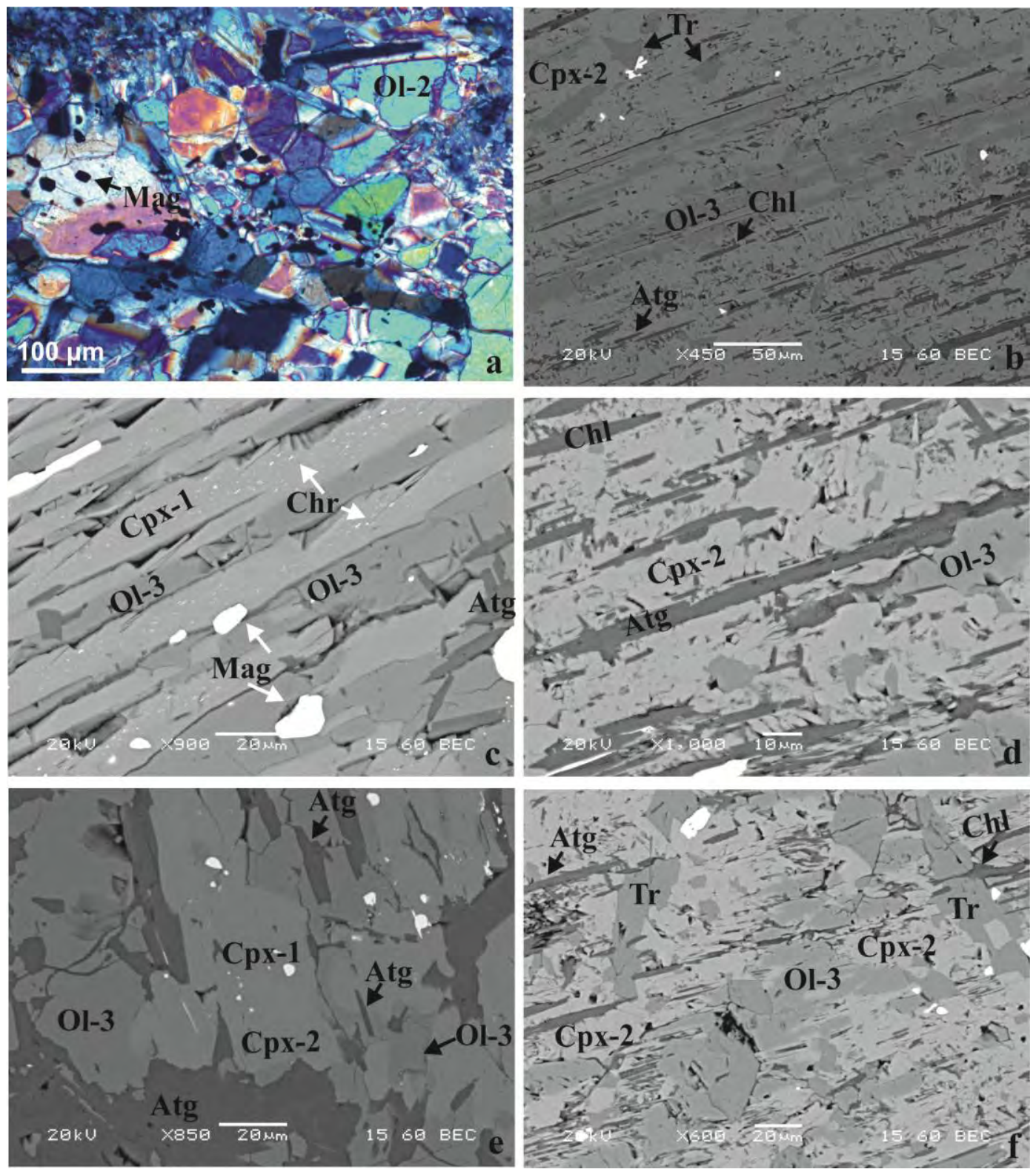

Figure 2 - Metalherzolite LZ-A1: a) Photomicrograph of isometric olivive grains (Ol-2) with inclusions of $\mathrm{Cr}$-magnetite (black inclusions) b) Back-Scattered Electron (BSE) image of primary clinopyroxene replaced by diopside (Cpx-2), olivine (Ol-3), tremolite (Tr), antigorite (Atg) and chlorite (Chl). c) BSE image of lamellar clinopyroxene (Cpx-1) containing tiny chromite exsolutions. (Ol-3)=lamellar olivine, white grains $\mathrm{Cr}$-magnetite, Atg=antigorite. d) BSE image pf alternating diopside (Cpx-2), antigorite and chlorite lamellae. The chlorite lamellae are in contact with lamellar olivine (Ol-3). e) BSE image of a zoned clinopyroxene $\left(\mathrm{Al}_{2} \mathrm{O}_{3}=1.16\right.$ wt \% core, $\mathrm{Al}_{2} \mathrm{O}_{3}=0$ rim) with $\mathrm{Cr}$-magnetite inclusions. Diopside $(\mathrm{Cpx})$ contains antigorite inclusions and is marginally replaced by olivine (Ol-3). An antigorite flake is enclosed in diopside and in the overgrown olivine. f) BSE image of diopside (Cpx-2) and antigorite replaced by olivine (OI-3), chlorite and tremolite. Tremolite contains inclusion of diopside (right edge of the picture). Antigorite, olivine and chlorite are lamellar in shape and oriented in diopside. 


\section{Mineral Chemistry}

Two samples from the metalherzolites, LZ-K1 and LZ-A1, (major and minor element- and norm compositions are given in Table 1), were selected for analyses of the mineral compositions. In sample LZ-K1, which shows a low degree of the metamorphic overprint, the mantle assemblage $\mathrm{Ol}-1+\mathrm{Opx}+\mathrm{Cpx}-1+\mathrm{Cr}-\mathrm{Spl}$ dominates, whereas in sample LZ-A1, the metamorphic assemblage $\mathrm{Atg}+\mathrm{Ol}-2+\mathrm{Tr}+\mathrm{Chl}+\mathrm{Ol}-3+\mathrm{Cr}-\mathrm{Mag}$ dominates. Relicts of Ol-1 and $\mathrm{Cpx}-1$ are preserved in both samples.

Table 2: Metalherzolite: Representative microprobe analyses of orthopyroxene, clinopyroxene, olivine, antigorite, chlorite, tremolite, $\mathrm{Cr}$-spinel and $\mathrm{Cr}$-magnetite.

\begin{tabular}{|c|c|c|c|c|c|c|c|c|c|c|c|}
\hline & Opx & Opx & Cpx-1 & Cpx-1 & Cpx-2 & Cpx-2 & Ol-1 & Ol-2/3 & $\mathrm{Tr}$ & Atg & Atg \\
\hline $\mathrm{SiO}_{2}$ & 55.59 & 55.50 & 52.00 & 52.22 & \begin{tabular}{|l|}
55.13 \\
\end{tabular} & 55.02 & 40.90 & 40.95 & 58.52 & 41.07 & 42.11 \\
\hline $\mathrm{Al}_{2} \mathrm{O}_{3}$ & 3.13 & 2.36 & 4.15 & 4.04 & - & - & - & - & - & 2.84 & 1.23 \\
\hline $\mathrm{Cr}_{2} \mathrm{O}_{3}$ & 0.86 & 0.73 & 1.04 & 0.95 & - & 0.19 & - & - & - & 0.64 & - \\
\hline $\mathrm{FeO}_{\mathrm{t}}$ & 5.65 & 6.15 & 3.13 & 3.03 & 1.17 & 0.91 & 8.58 & 9.15 & 1.49 & 3.35 & 4.66 \\
\hline $\mathrm{MnO}$ & - & - & - & - & - & - & - & - & - & - & - \\
\hline $\mathrm{MgO}$ & 33.27 & 33.40 & 19.28 & 18.92 & 17.72 & 17.79 & 50.11 & 49.51 & 23.77 & 40.12 & 39.95 \\
\hline $\mathrm{NiO}$ & - & - & - & - & - & - & 0.37 & 0.41 & - & 0.16 & 0.28 \\
\hline $\mathrm{CaO}$ & 1.48 & 1.40 & 20.36 & 20.80 & 25.83 & 25.76 & - & - & 13.63 & - & - \\
\hline Total & 99.97 & 99.54 & 99.97 & 99.96 & 99.85 & 99.68 & 99.96 & 100.02 & 97.42 & 88.18 & 88.23 \\
\hline $\mathrm{Si}$ & 1.921 & 1.931 & 1.882 & 1.890 & 2.001 & 1.999 & 0.998 & 1.001 & 7.996 & 7.638 & 7.857 \\
\hline $\mathrm{Al}$ & 0.127 & 0.097 & 0.177 & 0.173 & - & - & - & - & - & 0.622 & 0.270 \\
\hline $\mathrm{Cr}$ & 0.025 & 0.020 & 0.030 & 0.027 & - & 0.005 & - & - & - & 0.094 & - \\
\hline $\mathrm{Fe}$ & 0.163 & 0.180 & 0.095 & 0.092 & 0.036 & 0.028 & 0.175 & 0.183 & 0.170 & 0.521 & 0.722 \\
\hline $\mathrm{Mn}$ & - & - & - & - & - & - & - & - & - & - & - \\
\hline $\mathrm{Mg}$ & 1.714 & 1.732 & 1.040 & 1.021 & 0.959 & 0.963 & 1.822 & 1.803 & 4.842 & 11.115 & 11.111 \\
\hline $\mathrm{Ni}$ & - & - & - & - & - & - & 0.007 & 0.008 & - & 0.024 & 0.042 \\
\hline $\mathrm{Ca}$ & 0.050 & 0.052 & 0.790 & 0.807 & 1.004 & 1.003 & - & - & 1.996 & - & - \\
\hline & & & & & & & & & & & \\
\hline & Atg & Atg & Chl & Chl & Chl & & Spl-c & Spl-r & Mag & Mag & Mag \\
\hline $\mathrm{SiO}_{2}$ & 40.78 & 41.77 & 30.64 & 34.81 & 33.52 & $\mathrm{Al}_{2} \mathrm{O}_{3}$ & 43.73 & 40.58 & - & 1.17 & - \\
\hline $\mathrm{Al}_{2} \mathrm{O}_{3}$ & 3.80 & 1.37 & 18.37 & 11.46 & 12.13 & $\mathrm{Cr}_{2} \mathrm{O}_{3}$ & 25.97 & 28.68 & 9.66 & 15.59 & 10.30 \\
\hline $\mathrm{Cr}_{2} \mathrm{O}_{3}$ & - & 0.67 & 2.49 & 2.36 & 3.78 & $\mathrm{Fe}_{2} \mathrm{O}_{3}$ & 0.11 & 0.19 & 59.67 & 53.57 & 59.85 \\
\hline $\mathrm{FeO}_{\mathrm{t}}$ & 3.38 & 5.82 & 3.17 & 3.42 & 3.68 & $\mathrm{FeO}$ & 13.34 & 15.21 & 28.52 & 25.74 & 26.93 \\
\hline $\mathrm{MnO}$ & - & - & - & - & - & $\mathrm{MnO}$ & 0.36 & 0.36 & - & 0.33 & 0.68 \\
\hline $\mathrm{MgO}$ & 39.83 & 38.28 & 33.34 & 35.61 & 34.57 & $\mathrm{MgO}$ & 16.57 & 14.96 & 1.16 & 3.13 & 2.13 \\
\hline $\mathrm{NiO}$ & 0.22 & 0.12 & - & - & - & $\mathrm{NiO}$ & - & - & 1.01 & 0.66 & 0.40 \\
\hline $\mathrm{CaO}$ & - & - & - & - & - & & & & & & \\
\hline Total & 88.01 & 88.06 & 88.02 & 87.69 & 87.69 & & 99.98 & 99.97 & 99.87 & 100.20 & 100.3 \\
\hline & & & & & & & & & & & \\
\hline $\mathrm{Si}$ & 7.579 & 7.864 & 5.755 & 6.558 & 6.359 & $\mathrm{Al}$ & 1.428 & 1.354 & - & 0.051 & - \\
\hline $\mathrm{Al}$ & 0.832 & 0.308 & 4.064 & 2.545 & 2.712 & $\mathrm{Cr}$ & 0.569 & 0.642 & 0.291 & 0.456 & 0.306 \\
\hline $\mathrm{Cr}$ & - & 0.100 & 0.369 & 0.352 & 0.568 & $\mathrm{Fe}^{3+}$ & 0.002 & 0.004 & 1.709 & 1.492 & 1.694 \\
\hline $\mathrm{Fe}$ & 3.380 & 0.917 & 0.498 & 0.538 & 0.584 & $\mathrm{Fe}^{2+}$ & 0.309 & 0.360 & 0.903 & 0.797 & 0.847 \\
\hline $\mathrm{Mn}$ & - & - & - & - & - & $\mathrm{Mn}$ & 0.008 & 0.009 & - & 0.010 & 0.022 \\
\hline $\mathrm{Mg}$ & 39.830 & 10.742 & 9.355 & 10.000 & 9.777 & $\mathrm{Mg}$ & 0.685 & 0.631 & 0.066 & 0.173 & 0.119 \\
\hline $\mathrm{Ni}$ & 0.220 & 0.020 & - & - & - & $\mathrm{Ni}$ & - & - & 0.031 & 0.020 & 0.012 \\
\hline $\mathrm{Ca}$ & - & - & - & - & - & & & & & & \\
\hline
\end{tabular}

$\mathrm{c}=\mathrm{core}, \mathrm{r}=$ rim. Analyses were performed using a JEOL $6380 \mathrm{LV}$ SEM equipped with energy dispersive system (EDS) at the School of Mining and Metallurgical Engineering, National Technical University of Athens. Representative mineral compositions are given in Table 2.

\subsection{Mantle Assemblage:}

The forsterite component in olivine (Ol-1) ranges between $\mathrm{Fo}_{0.89}$ and $\mathrm{Fo}_{0.91}$. In orthopyroxene the $\mathrm{Al}_{2} \mathrm{O}_{3}$ content ranges from 2.27 to $3.13 \mathrm{wt} \%$, the $\mathrm{Cr}_{2} \mathrm{O}_{3}$ from 0.46 to $0.86 \mathrm{wt} \%$, the $\mathrm{CaO}$ content 
from 1.27 to $1.48 \mathrm{wt} \%$ and the $\mathrm{Mg} /(\mathrm{Mg}+\mathrm{Fe})$ ratio from 0.9 to 0.91 . Mantle clinopyroxene $(\mathrm{Cpx}-$ 1) is Cr-diopside. The $\mathrm{Al}_{2} \mathrm{O}_{3}$ content ranges from 1.73 to $4.15 \mathrm{wt} \%$, the $\mathrm{Cr}_{2} \mathrm{O}_{3}$ from 0.48 to 1.92 wt $\%$ and the $\mathrm{Mg} /(\mathrm{Mg}+\mathrm{Fe})$ ratio from 0.92 to 0.94 . Lower $\mathrm{Al}_{2} \mathrm{O}_{3}$ contents show rim compositions in zoned ortho- and clinopyroxene grains. Chromite is $\mathrm{Cr}$-spinel with $\mathrm{Cr} /\left(\mathrm{Cr}+\mathrm{Al}+\mathrm{Fe}^{3+}\right)$ ratio 0.28 in the core and 0.32 at the rim and $\mathrm{Mg} /\left(\mathrm{Mg}+\mathrm{Fe}^{2+}\right)$ ratio 0.68 and 0.63 respectively. The decrease in $\mathrm{Al}$ and $\mathrm{Mg}$ content from the core to the rim is attributed to alteration and partial replacement of the Cr-spinel by chlorite during the metamorphic processes.

\subsection{Metamorphic assemblage:}

The forsterite component in $\mathrm{Ol}-2$ and $\mathrm{Ol}-3$ ranges between $\mathrm{Fo}_{0.90}$ and $\mathrm{Fo}_{0.91}$. No remarkable differences are observed in the forsterite component between mantle Ol-1 and metamorphic Ol-2 and Ol-3. $\mathrm{Cpx}-2$ shows a higher $\mathrm{Mg} /(\mathrm{Mg}+\mathrm{Fe})$ ratio (0.96-0.97) compared to that of $\mathrm{Cpx}-1$ (0.920.94). In Cpx-2 the $\mathrm{Al}_{2} \mathrm{O}_{3}$ content is below the detection limit and the $\mathrm{Cr}_{2} \mathrm{O}_{3}$ content from 0 to 0.19 $\mathrm{wt} \%$. Antigorite contains appreciable amounts of aluminium. The $\mathrm{Al}_{2} \mathrm{O}_{3}$ content ranges from 0.5 to $4.28 \mathrm{wt} \%$. Higher $\mathrm{Al}_{2} \mathrm{O}_{3}$ values are measured in antigorite flakes replacing $\mathrm{Cpx}-1$. $\mathrm{The} \mathrm{Cr}_{2} \mathrm{O}_{3}$ content ranges from 0 to $1.52 \mathrm{wt} \%$. Chlorite is clinochlore with 5.75 to $6.70 \mathrm{Si}$ atoms per formula unit (a.p.f.u.), 2.21 to $4.06 \mathrm{Al}$ a.p.f.u. and a $\mathrm{Mg} /(\mathrm{Mg}+\mathrm{Fe})$ ratio ranging from 0.93 to 0.95 . The $\mathrm{Cr}_{2} \mathrm{O}_{3}$ content in chlorite ranges from 2.36 to $3.78 \mathrm{wt} \%$ and total iron, expressed as $\mathrm{FeO}$, from 3.17 to 4.49 wt $\%$. The $\mathrm{Mg} /(\mathrm{Mg}+\mathrm{Fe})$ ratio in tremolite ranges between 0.95 to 0.98 ; the $\mathrm{Al}_{2} \mathrm{O}_{3}$ content is below the detection limit. Cr-magnetite is formed at the expense of primary spinel, olivine (Ol-1), and clinopyroxene within the stability field of antigorite during the serpentinization. The Cr-magnetite inclusions in Ol-2 (Figure 2b) indicate that it is formed at an early stage of the prograde path of metamorphism. The $\mathrm{Cr}_{2} \mathrm{O}_{3}$ content ranges from 9.21 to $14.95 \mathrm{wt} \%$, the $\mathrm{MgO}$ from 0 to $1.9 \mathrm{wt} \%$, the $\mathrm{NiO}$ from 0.23 to $1.45 \mathrm{wt} \%$ and the $\mathrm{Al}_{2} \mathrm{O}_{3}$ content from 0 to $1.17 \mathrm{wt} \%$.

\section{Discussion}

Textural relationships, mineral assemblages and mineral compositions in the metalherzolite pockets indicate that the Kechros metaperidotite is affected by the HP metamorphic event recorded in the neighboring crustal rocks (Mposkos, 1989; Mposkos et al., 2011). The mantle assemblage was $\mathrm{Ol}-1+\mathrm{Opx}+\mathrm{Cpx}-1+\mathrm{Cr}-\mathrm{Spl}$ and the metamorphic assemblage is Atg $+\mathrm{Ol}-2+\mathrm{Cpx}-2+\mathrm{Ol}-$ $3+\mathrm{Chl}+\mathrm{Tr}+\mathrm{Cr}-\mathrm{Mag}$. Mantle olivine (Ol-1) and orthopyroxene are replaced by antigorite. Antigorite and Cr-magnetite are formed in an early stage of the metamorphic event as indicate antigorite and $\mathrm{Cr}$-magnetite inclusions in olivine (Ol-2 and Ol-3, Figure 2a). Antigorite occurs also as inclusion in Cr-magnetite. In most metalherzolite pockets orthopyroxene is absent. It is completely consumed by the antigorite forming reaction:

$$
\mathrm{Ol}+\mathrm{Opx}+\mathrm{W} \rightarrow \mathrm{Atg}
$$

With increasing metamorphic grade and by crossing the olivine plus antigorite stability field, Ol-2 is formed at the expense of antigorite. With further increase of the metamorphic grade, or during decompression, tremolite, olivine (Ol-3) and chlorite are formed at the expense of clinopyroxene $(\mathrm{Cpx}-1)$ and antigorite as suggested by the textural relationships (Figures 2b,e,f). Tremolite and olivine are formed according to the reaction:

$$
\mathrm{Atg}+\mathrm{Di} \rightarrow \mathrm{Ol}+\mathrm{Tr}+\mathrm{H}_{2} \mathrm{O}
$$

Antigorite lamellae in clinopyroxene are probably formed replacing lamellae of enstatite exsolutions in the primary clinopyroxene (Figures $2 \mathrm{~b}, \mathrm{~d}$ ) according to reaction 1 . Olivine lamellae in clinopyroxene (Figures. 2b,c) are formed replacing antigorite lamellae according to reaction 2.

Chlorite is also formed by the replacement of the clinopyroxene, in addition to tremolite and olivine-3 (Figure 2f). The Tschermak component of the primary clinopyroxene (Cpx-1) was consumed according to the reaction: 


$$
\mathrm{Atg}+\mathrm{Cts} \rightarrow \mathrm{Tr}+\mathrm{Fo}+\mathrm{Chl}+\mathrm{W}
$$

The $\mathrm{Al}_{2} \mathrm{O}_{3}$ content in antigorite (it ranges from 0.5 to $4.28 \mathrm{wt} \%$ ) was also an aluminum source for the chlorite formation.

The maximum P-T conditions were lower than those constrained by the reaction:

$$
\mathrm{Atg} \rightarrow \mathrm{Ol}+\mathrm{Tlc}+\mathrm{H}_{2} \mathrm{O}
$$

since antigorite is still stable and the assemblage olivine+talc was not formed.

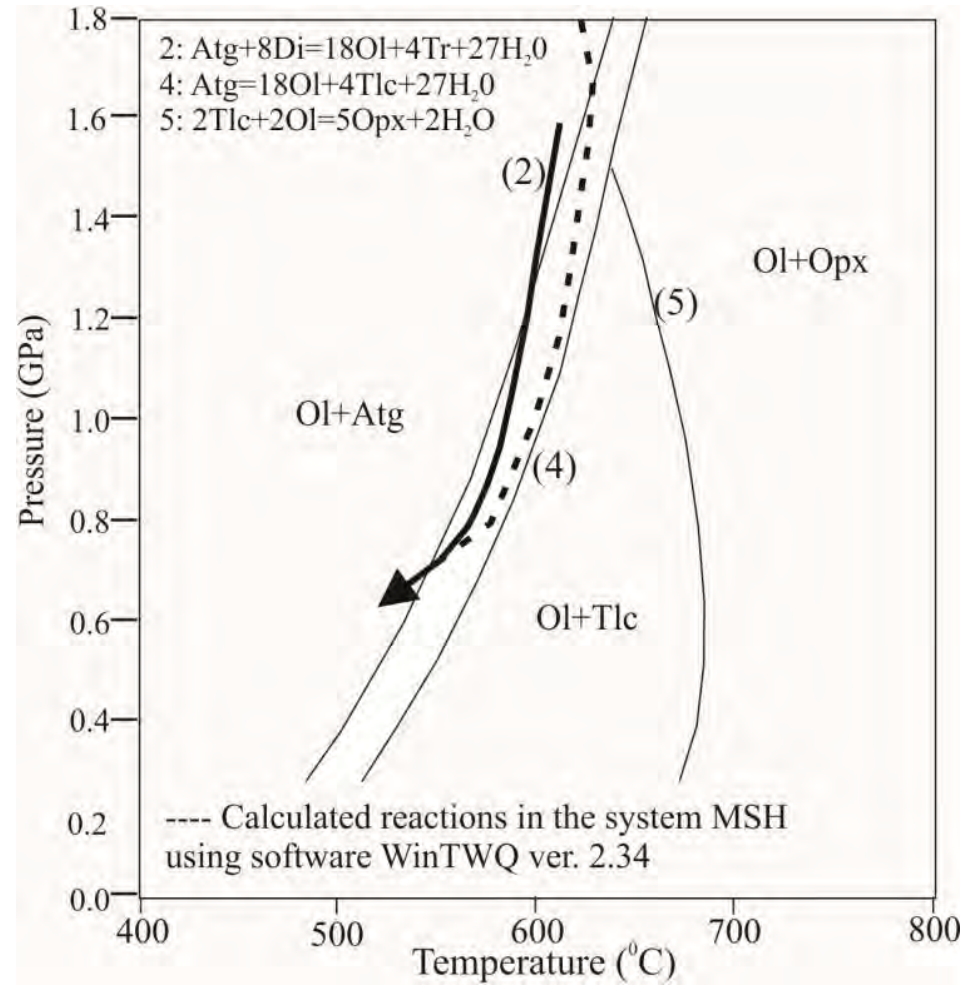

Figure 3 - Peak metamorphic PT conditions (adopted from neighboring eclogites, Mposkos et al., 2012, dotted line) and exhumation path of the Virsini metaperidotite from the Kechros complex in eastern Rhodope.

The metamorphic temperatures are constrained within the narrow field confined by the curves of the reactions 2 and 4 (Figure 3). This is also in accordance with the low Al-spinel component in the $\mathrm{Cr}$-magnetite (up to $\approx 2 \%$ ) which suggests that $\mathrm{Cr}$-magnetite is formed below the talc + olivine stability field (Evans and Frost, 1975). In talc-olivine rocks ferrit-chromites accommodate Alspinel component up to $5 \%$ and in chlorite-enstatite-olivine rocks up to $35 \%$ (Evans and Frost, 1975; Mposkos et al., 2010). Boudins of amphibolitized eclogites and of omphacite-bearing metatrondhjemites within the Virsini metaperidotite (Mposkos et al., 2012; Mposkos et al., 2013) indicate that the Kechros ultramafic rocks are metamorphosed at high pressures. For pressure of about $1.7 \mathrm{GPa}$ (recorded in neighbouring eclogites) and assuming that the reaction 2 occurred at the prograde stage of metamorphism, the maximum temperature in the metaperidotite is constrained between 610 and $630{ }^{\circ} \mathrm{C}$ which is slightly higher than that obtained from the associated eclogites $\left(\approx 570{ }^{\circ} \mathrm{C}\right.$ at $1.7 \mathrm{GPa}$; Mposkos et al., 2012). At peak temperature of approximately $570{ }^{\circ} \mathrm{C}$ the curve of the reaction 2 is crossed during decompression. Assuming isothermal decompression as was recorded in the associated eclogites and metapelites the reaction curve was crossed at a pressure of $\sim 1.2 \mathrm{GPa}$ (Figure 3). 


\section{Conclusions}

The Virsini metaperidotite from the Kechros HP metamorphic complex in eastern Rhodope is a sepentinized clinopyroxene-bearing harzburgite with pockets of lherzolitic composition. Dykes of amphibolitized eclogites and omphacite bearing metatrondjemites within the metaperidotite indicate that the metaperidotite underwent HP metamorphism similar to that recorded in the associated rocks of the continental crust assemblage.

In the metalherzolite pockets the mantle assemblage is Ol-1+Opx $+\mathrm{Cpx}-1+\mathrm{Cr}-\mathrm{Spl}$. The metamorphic assemblage is Atg $+\mathrm{Ol}-2+\mathrm{Cpx}-2+\mathrm{Ol}-3+\mathrm{Chl}+\mathrm{Tr}+\mathrm{Cr}-\mathrm{Mag}$. Antigorite and $\mathrm{Cr}-$ magnetite are formed in an early stage of the metamorphic event. Antigorite lamellae in clinopyroxene are probably formed replacing lamellae of "enstatite exsolutions" in the primary clinopyroxene. With increasing metamorphic grade and by crossing the olivine plus antigorite stability field olivine (Ol-2) is formed at the expense of antigorite. With further increase of metamorphic grade (or more probably during decompression), tremolite, olivine (Ol-3) and chlorite are formed at the expense of clinopyroxene and antigorite. Olivine lamellae in clinopyroxene replace antigorite- or former orthopyroxene lamellae in clinopyroxene. The aluminum source for the chlorite formation was the $\mathrm{Al}_{2} \mathrm{O}_{3}$ content in antigorite (up to 4.28 wt \%) and the Tschermak component of the primary pyroxenes. The metamorphic temperatures are constrained within the stability field of the mineral assemblage Atg $+\mathrm{Ol}+\mathrm{Tr}$ (Figure 3). At peak PT conditions $\left(\approx 1.7 \mathrm{GPa} / 570{ }^{\circ} \mathrm{C}\right.$ recorded in neighbouring eclogites $)$ the curve of the reaction $\mathrm{Di}+\mathrm{Atg} \rightarrow \mathrm{Ol}+\mathrm{Tr}+\mathrm{H}_{2} \mathrm{O}$ is crossed during decompression.

\section{References}

Burg J.P. 2011. Rhodope: From Mesozoic convergence to Cenozoic extension. Review of petrostructural data in the geochronological frame, Journal of the Virtual Explorer, 39, 1-44.

Brueckner H.K. and Medaris L.G. 2000. A general model for the intrusion and evolution of "mantle" garnet peridotites in high-pressure and ultra-high-pressure metamorphic terranes. Journal of Metamorphic Geology, 18, 123-133.

Cornelius N.K. 2008: UHP metamorphic rocks of the Eastern Rhodope Massif, NE Greece: new constraints from petrology, geochemistry and zircon ages, PhD Thesis, Johannes-Gutenberg Universität, Mainz.

Del Moro A., Innocenti F., Kyriakopoulos C., Manetti P. and Papadopoulos P. 1988. Tertiary granitoids from Thrace (Northern Greece): $\mathrm{Sr}$ isotopic and petrochemical data. Neues Jahrbuch fuer Mineralogie Abhandlungen, 159, 113-135.

Evans B.W. and Frost B.R. 1975. Chrome-spinel in progressive metamorphism-a preliminary analysis. Geochimica et Cosmochimica Acta, 39, 959-972.

Iliadis A 2006. Study of the ultrabasic rocks of Ano Virsini (Geology-Petrology-Metallogeny), PhD Thesis, National Technical University of Athens, pp. 236 (In Greek with English abstract).

Krohe A. and Mposkos E. 2002. Multiple generations of extensional detachments in the Rhodope Mountains (N.Greece): evidence of episodic exhumation of high-P rocks. In: Blundell, D.J., Neubauer, G. and Von Quant, A. (eds.): The timing and location of major ore deposits in an evolving orogen, Geological Society of London, Special Publication 204, 151-178.

Liati A., Gebauer D. and Fanning M. 2011. Geochronology of the Alpine UHP Rhodope zone: A review of isotopic ages and constraints on the geodynamic evolution. In Dobrzhinetskaya et al (ed), Ultrahigh-Pressure Metamorphism. 25 years after the discovery of coesite and diamond (ed) Dobrzhinetskaya et al. Elsevier, 295-324.

Lips A.L.W., White S.H. and Wijbrans J.R. 2000. Middle-Late Alpine thermotectonic evolution of the southern Rhodope Massif, Greece, Geodinamica Acta, 13, 281-292. 
Mposkos E. 1989. High-pressure metamorphism in gneisses and pelitic schist in the East Rhodope zone (N Greece), Mineralogy and Petrology, 41, 25-39.

Mposkos E. and Krohe A. 2000. Petrological and structural evolution of continental high pressure (HP) metamorphic rocks in the Alpine Rhodope domain (N.Greece), Proceedings of the 3rd International Conference on the Geology of the Eastern Mediterranean, 221-232.

Mposkos E. and Liati A. 1993. Metamorphic evolution of metapelites in the high-pressure terrane of the Rhodope zone, northern Greece, Canadian Mineralogist, 31, 401-424.

Mposkos E. and Wawrzenitz N. 1995. Metapegmatites and pegmatites bracketing the time of HPmetamorphism in polymetamorphic rocks of the E Rhodope, N Greece: petrological and geochronological constraints, Geological Society of Greece Special Publication, 4, 602-608

Mposkos E. and Krohe A. 2006. P-T-deformation paths of closely associated UHP (diamondbearing) crustal and mantle rocks of the Kimi Complex: Implications for the tectonic history of the Rhodope Mountains, northern Greece, Canadian Journal of Earth Sciences, 43, $1755-1776$.

Mposkos E., Baziotis I. and Proyer A. 2010. Metamorphic reprocessing of a serpentinized carbonate-bearing peridotite after detachment from the mantle wedge: A P-T path constrained from textures and phase diagrams in the system $\mathrm{CaO}-\mathrm{MgO}-\mathrm{Al}_{2} \mathrm{O}_{3}-\mathrm{SiO}_{2}-\mathrm{CO}_{2}-\mathrm{H}_{2} \mathrm{O}$, Lithos, $118,349-364$.

Mposkos E., Baziotis I. and Proyer A. 2011. Pressure-temperature evolution of eclogites from the Kechros complex in the Eastern Rhodope (NE Greece), International Journal of Earth Sciences (Geologische Rundschau) DOI 10.1007/s00531-011-0699-2.

Mposkos E., Baziotis I. Leontakianakos G. and Barry P.H. 1012. The metamorphic evolution of the high-pressure Kechros complex in East Rhodope (NE Greece): implications from NaAl-rich leucocratic rocks within antigorite serpentinites, Lithos, submitted.

Padron-Navarta J.A., Sanchez-Vincaino V.L., Garrido C. and Gomez-Pugnaire M.T. 2011. Metamorphic record of high-pressure dehydration of antigorite serpentinite to chlorite harzburgite in a subduction setting (Cerro del Almirez, Nevado-Filabride complex, southern Spain, Journal of Petrology, 52, 2047-2078.

Peytcheva I. and von Quadt A. 1995. U-Pb zircon dating of metagranites from Byala Reka region in the east Rhodopes, Bulgaria, Proceedings XV Congress of the Carpathian-Balkan Geological Association, Special Publication, 4, 637-642, Geological Society of Greece, Athens.

Trommsdorff V. and Evans B.W. 1974. Alpine metamorphism of peridotitic rocks, Schweizerische Mineralogische Petrologische Mitteilungen, 54, 333-52.

Wawrzenitz N. and Mposkos E. 1997. First evidence for Lower Cretaceous HP/HT-metamorphism in the eastern Rhodope, North Aegean region, North-East Greece. European Journal of Mineralogy, 9, 659-664.

Whitney D. and Evans B.W. 2010. Abbreviations for names of rock-forming minerals, American Mineralogist, 95, 185-187. 